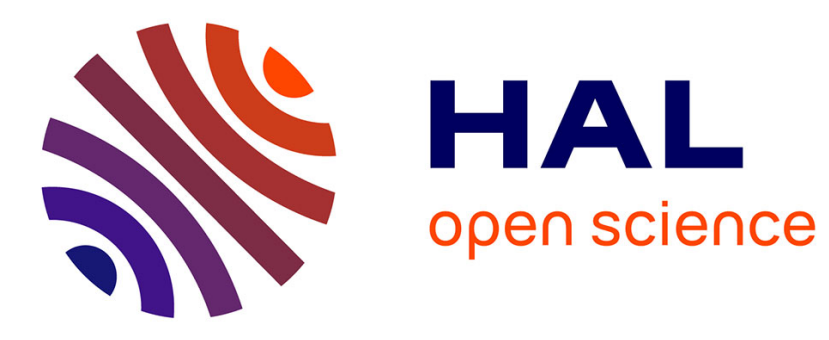

\title{
Pulsed electrical discharges in water for removal of organic pollutants: a comparative study
}

\author{
T.H. Dang, A. Denat, O. Lesaint, G. Teissedre
}

\section{To cite this version:}

T.H. Dang, A. Denat, O. Lesaint, G. Teissedre. Pulsed electrical discharges in water for removal of organic pollutants: a comparative study. European Physical Journal: Applied Physics, 2009, 47 (2), pp.1-7. 10.1051/epjap/2009110 . hal-00489491

\section{HAL Id: hal-00489491 \\ https://hal.science/hal-00489491}

Submitted on 5 Jun 2010

HAL is a multi-disciplinary open access archive for the deposit and dissemination of scientific research documents, whether they are published or not. The documents may come from teaching and research institutions in France or abroad, or from public or private research centers.
L'archive ouverte pluridisciplinaire HAL, est destinée au dépôt et à la diffusion de documents scientifiques de niveau recherche, publiés ou non, émanant des établissements d'enseignement et de recherche français ou étrangers, des laboratoires publics ou privés. 


\title{
PULSED ELECTRICAL DISCHARGES IN WATER FOR REMOVAL OF ORGANIC POLLUTANTS: A COMPARATIVE STUDY
}

\author{
T.H. Dang, A. Denat, O. Lesaint and G. Teissedre \\ Grenoble Electrical Engineering Laboratory (G2E lab) \\ CNRS and Grenoble University \\ Adress : G2E lab, CNRS, 25 rue des Martyrs, BP 166, 38042 Grenoble, FRANCE
}

\begin{abstract}
In this study, the efficiency of different types of pulsed electrical discharges for the removal of organic pollutants from wastewater has been determined. Three discharge types, either in the water volume or in close proximity to the water surface are studied. The production of hydrogen peroxide in pure water, and the degradation of two typical pollutants (4-chlorophenol and 4-nitrophenol) is measured together with the amount of electrical energy dissipated in discharges. It is shown that the energy yield for the degradation of organic pollutants, expressed in terms of degraded moles per Joule, strongly depends on the discharge type. The highest efficiency is obtained with pulsed corona discharges in humid air above the water surface. A lower efficiency is found with spark discharges in water, and the less efficient process is constituted by streamer discharges in water. The influence of ferrous ions added to solutions is also very different according to the discharge type. This helps to get a better understanding of the degradation processes involved with the different discharge types.
\end{abstract}

\section{INTRODUCTION}

Pulsed high-voltage discharge techniques are closely related to advanced oxidation processes (AOPs) as they induce simultaneously several physical effects (UV light, shock waves) and chemically active species such as ${ }^{\circ} \mathrm{OH},{ }^{\circ} \mathrm{H},{ }^{\circ} \mathrm{O},{ }^{\circ} \mathrm{HO}_{2}, \mathrm{H}_{2} \mathrm{O}_{2}, \mathrm{O}_{3}$, able to degrade harmful organic compounds in wastewater. Previous studies have shown the possibility to degrade organic pollutants in water by pulsed discharges, generated either directly in water or in the gas phase in close proximity to the liquid surface. Several pulsed discharges types can be used: "streamer" discharges in water, "spark" discharges in water (also frequently called "pulsed arc" or "electrohydraulic discharge"), "corona" in the gas above the liquid surface (air, nitrogen, argon, etc.), etc. [1-13]. In most cases, pulsed discharges were generated using point-plane electrode geometry, with a positive voltage applied to the point.

In a previous study of streamers in water [13], we have established the correlation between the electrical energy dissipated and chemical effects. The electrical energy delivered during the development of streamers in water depends on several parameters: conductivity, applied voltage. The amount of either hydrogen peroxide $\mathrm{H}_{2} \mathrm{O}_{2}$ generated or pollutants degraded is proportional to the energy input, but the chemical yield of reactions (in terms of mole per Joule) remains quite constant and does not depend on conductivity or voltage. On the other hand, it was shown that the addition of ferrous ions to contaminated water increases considerably the removal rate of pollutants such as 4chlorophenol and 4-nitrophenol, due to the enhanced production of ${ }^{\circ} \mathrm{OH}$ radicals via Fenton's reaction.

In this paper, we compare the efficiency of several pulsed discharge processes to generate hydrogen peroxide and degrade two typical organic molecules: 4-chlorophenol $(\mathrm{ClPh}$, an organic pollutant which can be degraded by various processes) and 4-nitrophenol (NiPh, a pollutant resistant to UV photolysis). Streamers in water, sparks in water, and corona in humid air above the water surface have been investigated. For pulsed streamers and sparks in water, the production of active chemical species $\left({ }^{\circ} \mathrm{OH},{ }^{\circ} \mathrm{H},{ }^{\circ} \mathrm{O}, \mathrm{H}_{2} \mathrm{O}_{2}\right)$ was previously proved by emission spectroscopy and chemical measurements. In addition to these active species, ozone as well as excited atomic and molecular nitrogen $\left(\mathrm{N}^{*}, \mathrm{~N}_{2}{ }^{*}\right.$, etc.) are produced by corona discharges in humid air. The influence of ferrous ions has also been measured 
for each discharge type.

Streamer and spark discharges in water are generated in a point-plane geometry under impulse voltage. Streamer discharges correspond to the development of numerous thin luminous filaments in the water. Filaments are about $10 \mu \mathrm{m}$ in diameter, and propagate at a velocity close to $30 \mathrm{~km} / \mathrm{s}$. While they propagate, the temperature and pressure inside filaments are very high (pressure in the propagating streamer head was estimated to be in the GPa range [18]). This pressure rapidly drops while the gaseous filament expands. The transition to breakdown occurs when the streamer reaches the opposite electrode. Breakdown is due to an electrical arc occurring in the vapor channels bridging the gap, resulting from the propagation of streamer filaments. Since the arc has a very high conductivity, the current strongly increases to a value depending on the arc resistance and on the external electrical circuit. In this study, arcs of short duration (a few $\mu$ s) are produced, and will be called "sparks". The energy dissipation by the spark contributes to further increase the vapor volume. The vapor pressure during the spark is not known in detail, but we may estimate that it is lower than in streamers, since the time duration (and hence gas expansion) of the spark is larger. Streamer and sparks in water induce UV light emission, shock waves, and generate chemically active species such as ${ }^{\circ} \mathrm{OH},{ }^{\circ} \mathrm{H}$ and ${ }^{\circ} \mathrm{O}$. The selection of the discharge type (streamer or streamer + spark) is made by changing the gap distance and the impulse voltage shape.

Pulsed corona discharges in humid air above the water surface are generated from a multipin anode situated $1 \mathrm{~cm}$ above the water surface, following the system described by Hoeben et al. [6,7]. This discharge type generates active species by excitation and ionization of $\mathrm{N}_{2}, \mathrm{O}_{2}$ and $\mathrm{H}_{2} \mathrm{O}$. Then, these species can react at the water surface and in the liquid volume after dissolution.

\section{EXPERIMENTAL METHODS}

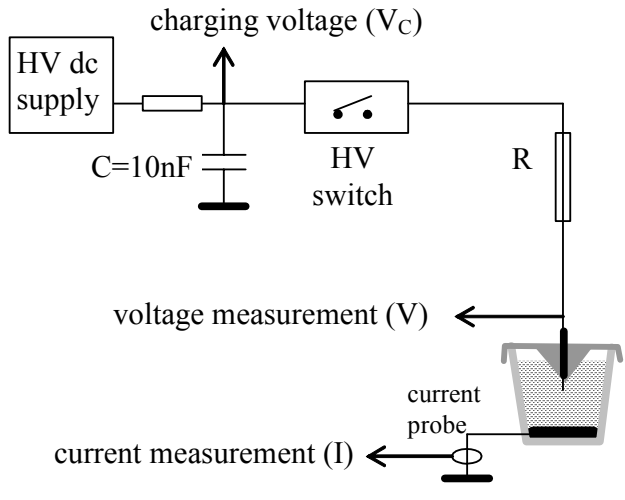

(a)

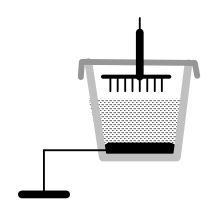

(b)

FIGURE1. (a) experimental set-up for streamer and sparks in water, (b) multipin test cell used for corona in air above the water surface. Current probe: $20 \mathrm{MHz}$ current transformer (Rogowski coil).

The principle of experiments is described in figure 1. For streamer and spark discharges in water, the point-plane gap is constituted by a tungsten wire ( $4 \mathrm{~mm}$ length, $200 \mu \mathrm{m}$ diameter) emerging from a Teflon $^{\mathrm{TM}}$ holder, facing a stainless steel plane $(50 \mathrm{~mm}$ diameter, $\mathrm{d}=20$ to $40 \mathrm{~mm}$ point-plane distance). The tungsten wire, eroded by discharges during experiments, was periodically renewed. The liquid volume in the test cell was $225 \mathrm{ml}$.

In these experiments, the classical rotating spark gap used in many experiments to generate high voltage pulses was replaced by fast semiconductor high voltage switches, to get a better control of the voltage waveform. To generate streamers in water, an electronic high voltage switch based on MOS transistors (Behlke ${ }^{\mathrm{TM}}$ HTS 600-10) was used. More details about this system and its advantages can be 
found in [13]. Contrary to a spark gap, the MOS switch can be opened before the capacitor C is fully discharged, providing the possibility to generate HV pulses of short duration. In water, breakdown occurs when the streamer initiated at the point reaches the plane electrode. If the HV pulse duration is smaller than the streamer crossing time (about $1.3 \mu$ s with a $40 \mathrm{~mm}$ gap distance), breakdown does not occur. In our experiments the pulse duration was fixed to $0.8 \mu$ s (see figure 2), and no breakdown occurred with voltage up to $50 \mathrm{kV}$ (with a $10 \mu$ s pulse, breakdown occurs at $30 \mathrm{kV}$ ). A resistor $\mathrm{R}(50$ to $600 \Omega$ ) was placed in series in order to limit the current in case of breakdown, below the maximum value allowed by the switch $(100 \mathrm{~A})$. Its influence on experiments was discussed in [13]. Chemical experiments were carried out with a $50 \mathrm{~Hz}$ pulse frequency.

Using the same test cell, the transition to a breakdown arc was obtained by reducing the gap distance to $20 \mathrm{~mm}$, and by using a HV pulse of longer duration. In this way, the streamer was able to reach the plane and induce breakdown. This was done by replacing the MOS switch by a Thyristor switch (Behlke ${ }^{\mathrm{TM}}$ HTS 640-100) operating basically as a spark gap (the switch remains closed until the capacitor $\mathrm{C}$ is fully discharged). In order to limit the current below the maximum value allowed by the switch (1000A), the resistance $\mathrm{R}$ was fixed to $50 \Omega$. The pulse frequency was $2 \mathrm{~Hz}$ during experiments. In this paper, the term "spark" is used to designate the transient breakdown arc of short duration (a few $\mu \mathrm{s})$ generated by this system.

For pulsed corona discharges in air above the liquid surface, a multipin electrode system derived from that described in $[6,7]$ was used (figure $1 \mathrm{~b}$ ). The high voltage electrode is made up of 41 tungsten thin wires $(200 \mu \mathrm{m}$ diameter, located at mutual distances of $5 \mathrm{~mm})$ placed at a distance $d=1 \mathrm{~cm}$ above the water solution. In contrast with the arrangement used in [6,7], no insulating solid was placed in series between the metallic plane electrode and the water. The same MOS switch as for streamers in water was used in these experiments, but the pulse width (at half value) increased to $4 \mu \mathrm{s}$ in this case.

\section{ELECTRICAL MEASUREMENTS}

Figure 2 illustrates typical measurements obtained respectively for streamer alone (a), streamer + spark discharges (b), and for corona discharges above the water surface (c). The oscilloscope trace 1 is the measured voltage $\mathrm{V}$ on the test cell, trace 2 : current I measured with a $20 \mathrm{MHz}$ current probe, trace 3: calculated instantaneous dissipated power $\mathrm{P}=\mathrm{VI}$, and trace 4: calculated energy $\mathrm{W}_{\text {imp }}$ (integration of the power P).

Streamers initiated in water with $\mathrm{V}=30 \mathrm{kV}$ appear immediately after the voltage rise (figure $2 \mathrm{a}$ ), and a current taking the form of a "hump" (about 20A in figure $2 \mathrm{a}$ ) is recorded while it propagates. The streamer current rapidly increases when either voltage or conductivity are increased [13]. Since the HV pulse duration is limited to $0.8 \mu \mathrm{s}$, no breakdown occurs (the streamer stops when the applied voltage drops to zero). With a fixed water conductivity, the electrical energy $\mathrm{W}_{\mathrm{imp}}$ is proportional to $\mathrm{V}^{4}$ [13]. In these experiments, carried out with an initial conductivity $\sigma_{0}$ of the solution of $100 \mu \mathrm{S} / \mathrm{cm}$, the typical value of energy per pulse $\mathrm{W}_{\text {imp }}$ was about $0.4 \mathrm{~J}$.

Spark discharges following the streamer phase take place by shortening the point-plane gap distance and increasing the HV pulse duration (figure $2 \mathrm{~b}$ ). On this figure, a streamer is first generated after the voltage rise, it propagates up to the plane and then induces breakdown at $\mathrm{t}=0.9 \mu \mathrm{s}$. During the streamer propagation, a current about 20A is recorded. When breakdown occurs (transition to an electrical arc), the current steeply raises up to $220 \mathrm{~A}$. At the same time the voltage on the test cell rapidly drops, due to both the influence of the series resistor $\mathrm{R}$, and the rapid discharge of the capacitor $\mathrm{C}$. The current decreases down to zero when the capacitor $\mathrm{C}$ is fully discharged. During breakdown, the shapes of current and voltage are determined by the external electrical circuit (including the capacitor $\mathrm{C}, \mathrm{HV}$ switch, and resistor R), and by the resistance of the breakdown arc itself. This resistance is highly nonlinear: it decreases first rapidly while a large current crosses the arc, and then increases when the current decreases to zero. The typical value of the total electrical energy per pulse $\mathrm{W}_{\text {imp }}$ is $2.5 \mathrm{~J}$, composed by the sum of the energy first released when the streamer propagates (about $0.5 \mathrm{~J}$ ), plus the energy later dissipated in the arc (2J). The pulse frequency was limited to $2 \mathrm{~Hz}$ to limit the temperature rise of the water solution. 


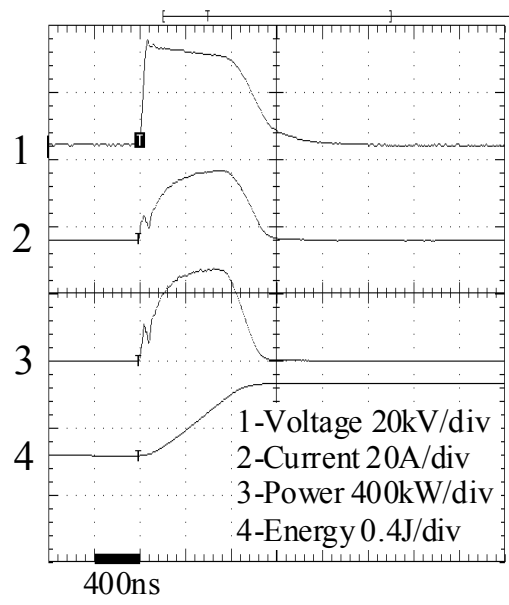

a)

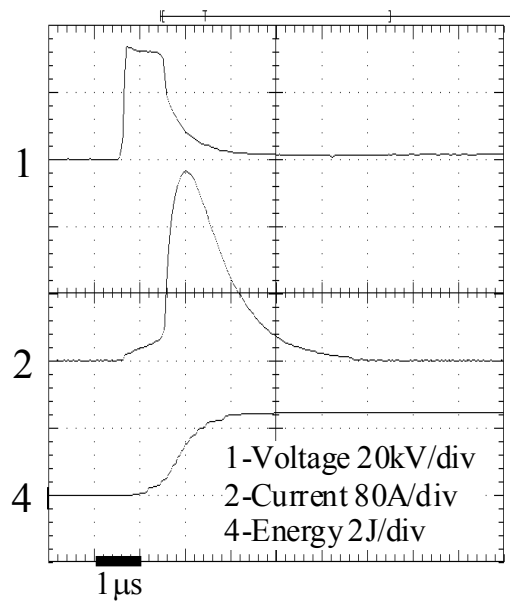

b)

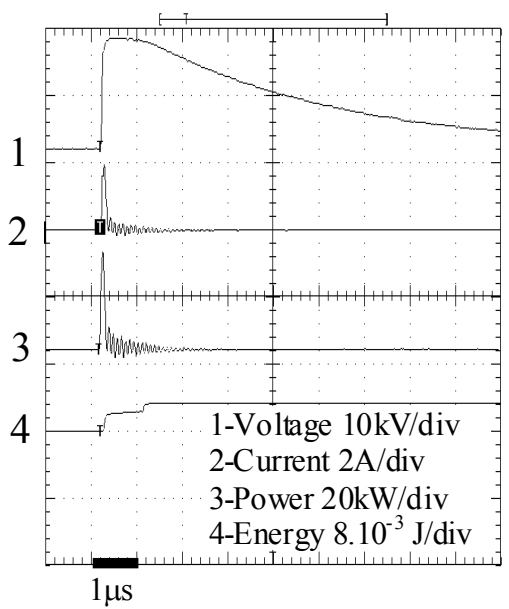

c)

FIGURE 2. Typical electrical measurements obtained for streamer (a), streamer + spark (b), and corona in humid air (c)

Figure 2c shows typical electrical measurements for corona discharges in air recorded at $16 \mathrm{kV}$. During the HV pulse, filamentary discharges of low luminous intensity quickly develop in air between each point and the water surface. The recorded current is made up of a fast pulse $(2 \mathrm{~A}, 0.1 \mu \mathrm{s})$ composed by the sum of the capacitive charging current of the test cell (during the voltage rise), plus the discharge current. At higher voltage (above $18 \mathrm{kV}$ ), a drastic change of the discharge process is recorded: discharge start to creep over the water surface, they become much more luminous, and a large current appears after the initial pulse, probably due to conduction through the water. During chemical experiments, the voltage was kept below this limit $(16 \mathrm{kV})$. To obtain the energy actually dissipated in discharges, the energy corresponding to the test cell charge (determined from measurements at lower voltage without discharges) was removed from the total measured energy, as described in $[6,7]$. The discharge energy per pulse is about $8 \mathrm{~mJ}$. The pulse frequency was increased to $500 \mathrm{~Hz}$ to obtain a reasonable input power. The volume of the solution was $100 \mathrm{ml}$.

\section{EXPERIMENTAL RESULTS AND DISCUSSION}

All experiments were done in demineralised and air-saturated water at ambient temperature. The initial conductivity $\sigma_{0}$ of solutions was adjusted to $100 \mu \mathrm{S} / \mathrm{cm}$ by adding $\mathrm{NaCl}$. The analytical grade reagents $\left(\mathrm{NaCl}, \mathrm{FeCl}_{2}\right.$, 4-chlorophenol and 4-nitrophenol) were used without further purification. All concentrations are given in mol/l, also noted $\mathrm{M}$. A magnetic stirring bar at the bottom of the test cell was used to keep the solution well homogenized for all discharges types.

\subsection{Pure water solution, $\sigma_{0}=100 \mu \mathrm{S} / \mathrm{cm}$}

Experiments were first carried out in a water solution without organic pollutants, with a conductivity increased to $100 \mu \mathrm{S} / \mathrm{cm}$ with $\mathrm{NaCl}$. The $\mathrm{pH}$ and conductivity recorded versus time are shown on figure 3 for the 3 discharge types. The temperature rise of the water under treatment remained below $10^{\circ} \mathrm{C}$, except for the case of streamer discharges, where a larger increase of temperature (up to $60^{\circ} \mathrm{C}$ ) occurred. The initial $\mathrm{pH}$ was about 6 and decreased at first rapidly and then slowly, down to a value depending on the discharge type. An increase of conductivity $\sigma$ was simultaneously recorded. The 
largest variations of $\mathrm{pH}$ and $\sigma$ are measured with corona discharges in humid air. This is quite logical if we consider that the formation of nitric and nitrite acids from nitrogen oxides occurs in the gas phase, before dissolution into the liquid [14,15]. However, the conductivity increase cannot be explained only by the $\mathrm{pH}$ change. After 100 minutes of corona discharges in humid air, conductivity increases from 100 to $516 \mu \mathrm{S} / \mathrm{cm}$ and $\mathrm{pH}$ decreases from 6.4 to 3.5, but the increase of conductivity can be only partly attributed ( $40 \%)$ to the increase in hydrogen (and nitrate) ion concentration. Some formation of salts or other ions must also occur [16].

For streamer and spark discharges in water, the variations of $\mathrm{pH}$ and conductivity versus time are lower, especially in the case of spark discharges (figure 3). Such discharges in water involve excitation, ionization and dissociation of water. By using the chemical reactions scheme proposed for pulsed radiolysis of air-saturated water, the calculated $\mathrm{pH}$ and conductivity variations remained always smaller than the experimental ones (e.g. we calculated $\mathrm{pH}=5.2$ for streamer discharges instead of an experimental value of 4.4, see fig. 3 ). Some reactions in the gaseous phase could also play a role.

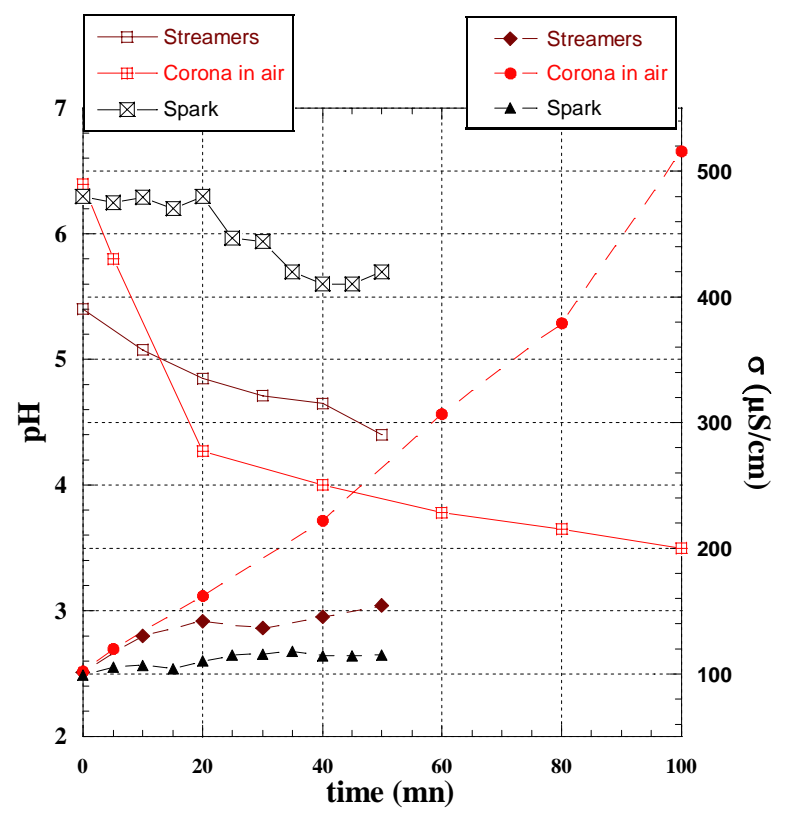

FIGURE 3. $\mathrm{pH}$ and conductivity variations versus time for the 3 discharge types in a pure water solution without organic pollutants, of initial conductivity $\sigma_{0}=100 \mu \mathrm{S} / \mathrm{cm}$.

With identical experimental conditions, the production of hydrogen peroxyde $\mathrm{H}_{2} \mathrm{O}_{2}$ in water was measured for the 3 discharge types, using a colorimetric method (Peroxyde CHEMets ${ }^{\circledR}$ test method based on the ferric thiocyanate chemistry). Figure 4 shows the production of $\mathrm{H}_{2} \mathrm{O}_{2}$ plotted versus accumulated input energy per liter $\mathrm{W}_{\mathrm{a}}$, for streamers in water at $\mathrm{V}=40 \mathrm{kV}$, sparks in water at $\mathrm{V}=35 \mathrm{kV}$, and corona in humid air at $\mathrm{V}=15.9 \mathrm{kV}$. In the case of streamers, a second series of experiments was carried out with a modified test cell equipped with a cooling jacket, in order to keep the solution temperature constant $\left(18^{\circ} \mathrm{C}\right)$.

All plots show the same initial variation: the concentration of $\mathrm{H}_{2} \mathrm{O}_{2}\left(\mathrm{c}_{\mathrm{H} 2 \mathrm{O} 2}\right)$ increases proportionally to the accumulated input energy per liter $\mathrm{W}_{\mathrm{a}}$. The energy yield $G_{\mathrm{H} 2 \mathrm{O} 2}$, defined as the number of $\mathrm{H}_{2} \mathrm{O}_{2}$ moles produced with $1 \mathrm{~J}$ energy, is practically independent of the discharge type $\left(\sim 6-810^{-9} \mathrm{~mol} / \mathrm{J}\right)$. Afterwards, the $\mathrm{H}_{2} \mathrm{O}_{2}$ concentration tends to saturate at a value that depends on the discharge type. For spark discharges in water and corona discharges in humid air, a small temperature rise $\left(<10^{\circ} \mathrm{C}\right)$ of the solution occurs, and the observed saturation results from the competition between formation and decomposition reactions of $\mathrm{H}_{2} \mathrm{O}_{2}$ in the plasma zone [17]. In humid air, the dissociation of water molecules by energetic electrons leads to the formation of $\mathrm{OH}$ radicals, and then to $\mathrm{H}_{2} \mathrm{O}_{2}$ which quickly dissolves in water due to its high solubility $\left(\sim 10^{5} \mathrm{M} / \mathrm{atm}\right)$. In our conditions $\mathrm{c}_{\mathrm{H} 2 \mathrm{O} 2}$ at saturation 
is about $300 \mu \mathrm{M}$ for spark discharges, and $\sim 400 \mu \mathrm{M}$ for corona discharges in humid air.

In the case of streamer discharges in water, a large difference in $\mathrm{H}_{2} \mathrm{O}_{2}$ saturation is observed with and without cooling of the solution. Without cooling, the large temperature rise (up to $60^{\circ} \mathrm{C}$ ) is responsible for the limitation of $\mathrm{c}_{\mathrm{H} 2 \mathrm{O} 2}$ at about $900 \mu \mathrm{M}$. With constant temperature $\left(18{ }^{\circ} \mathrm{C}\right)$, no saturation of $\mathrm{c}_{\mathrm{H} 2 \mathrm{O} 2}$ was recorded during experiments carried out for up to 2 hours.

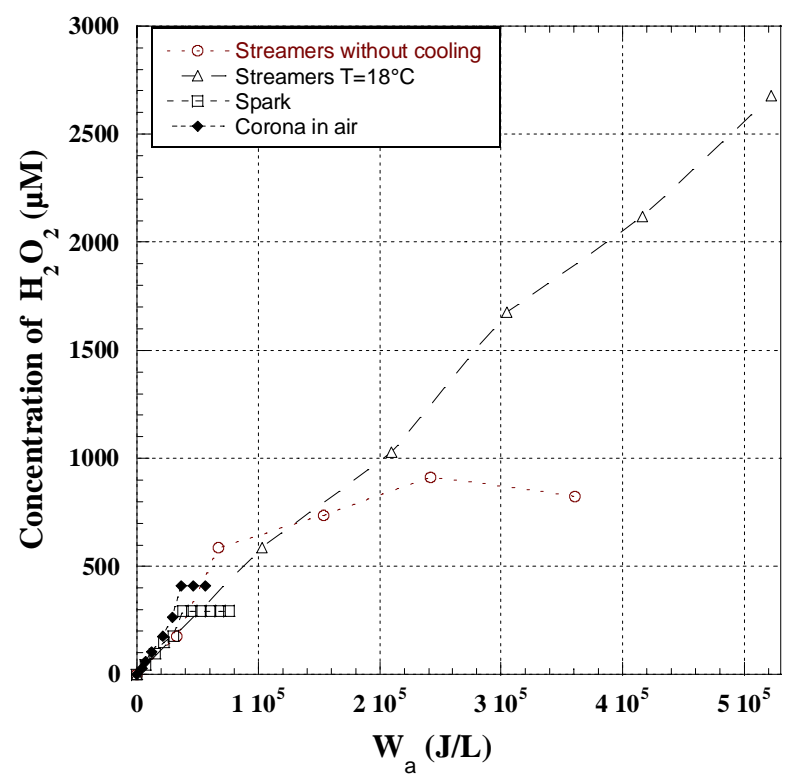

FIGURE 4. Production of $\mathrm{H}_{2} \mathrm{O}_{2}$ versus accumulated input energy per litre $\mathrm{W}_{\mathrm{a}}$, for the 3 discharge types. Initial conductivity $\sigma_{0}=100 \mu \mathrm{S} / \mathrm{cm}$.

\subsection{Water solutions with organic pollutants, $\sigma_{0}=100 \mu \mathrm{S} / \mathrm{cm}$}

We have tested the ability of the three discharge types to oxidize organic pollutants at room temperature. The concentration of pollutant (4-chlorophenol or 4-nitrophenol) and the formation of oxidized by-products were analyzed by HPLC (high performance liquid chromatograph) using a reversed phase C-18 column. The mobile phase $(0.8 \mathrm{ml} / \mathrm{mn})$ was a $60 / 40$ methanol/water mixture with $0.3 \%$ acetic acid. The UV detector wavelength was set at $270 \mathrm{~nm}$ for 4 -chlorophenol and $315 \mathrm{~nm}$ for $4-$ nitrophenol. In all experiments, the initial conductivity of solutions was adjusted to $100 \mu \mathrm{S} / \mathrm{cm}$ by adding $\mathrm{NaCl}$.

The $\mathrm{pH}$ and conductivity variations of solutions versus time were almost independent of the pollutant concentration, except for the case of spark discharges where the variations of $\mathrm{pH}$ and conductivity increased when pollutants were added to water. For instance, at the input energy $\mathrm{W}_{\mathrm{a}} \cong 310^{5} \mathrm{~J} / \mathrm{L}, \mathrm{pH}$ and conductivity were 6.0 and $115 \mu \mathrm{S} / \mathrm{cm}$ without pollutants, and 3.7 and $246 \mu \mathrm{S} / \mathrm{cm}$ with $100 \mu \mathrm{M}$ of $4-$ chlorophenol. This indicates a significant formation of organic acids from the oxidation of 4chlorophenol by spark discharges, contrary to the case of streamer in water or corona discharges in humid air.

The rate of 4-chlorophenol and 4-nitrophenol removal in water (initial concentration $\mathrm{c}_{0}=100 \mu \mathrm{M}$ and initial conductivity $\sigma_{0}=100 \mu \mathrm{S} / \mathrm{cm}$ ) strongly depends on the discharge type, and also on the addition of ferrous ions (figures 5 and 6). We have previously shown [13] that in the range $50<\mathrm{c}_{0}<250 \mu \mathrm{M}$ and $1<\sigma_{0}<200 \mu \mathrm{S} / \mathrm{cm}$, the relative pollutant concentration $\mathrm{c} / \mathrm{c}_{0}$ follows a pseudo-first-order reaction given by :

$$
\ln \left[\mathrm{c} / \mathrm{c}_{0}\right] \cong-k \mathrm{~W}_{\text {rel }}
$$

$\mathrm{W}_{\text {rel }}$ is the accumulated energy per mole $(\mathrm{J} / \mathrm{mol})$ and $k$ is the discharge chemical yield. 

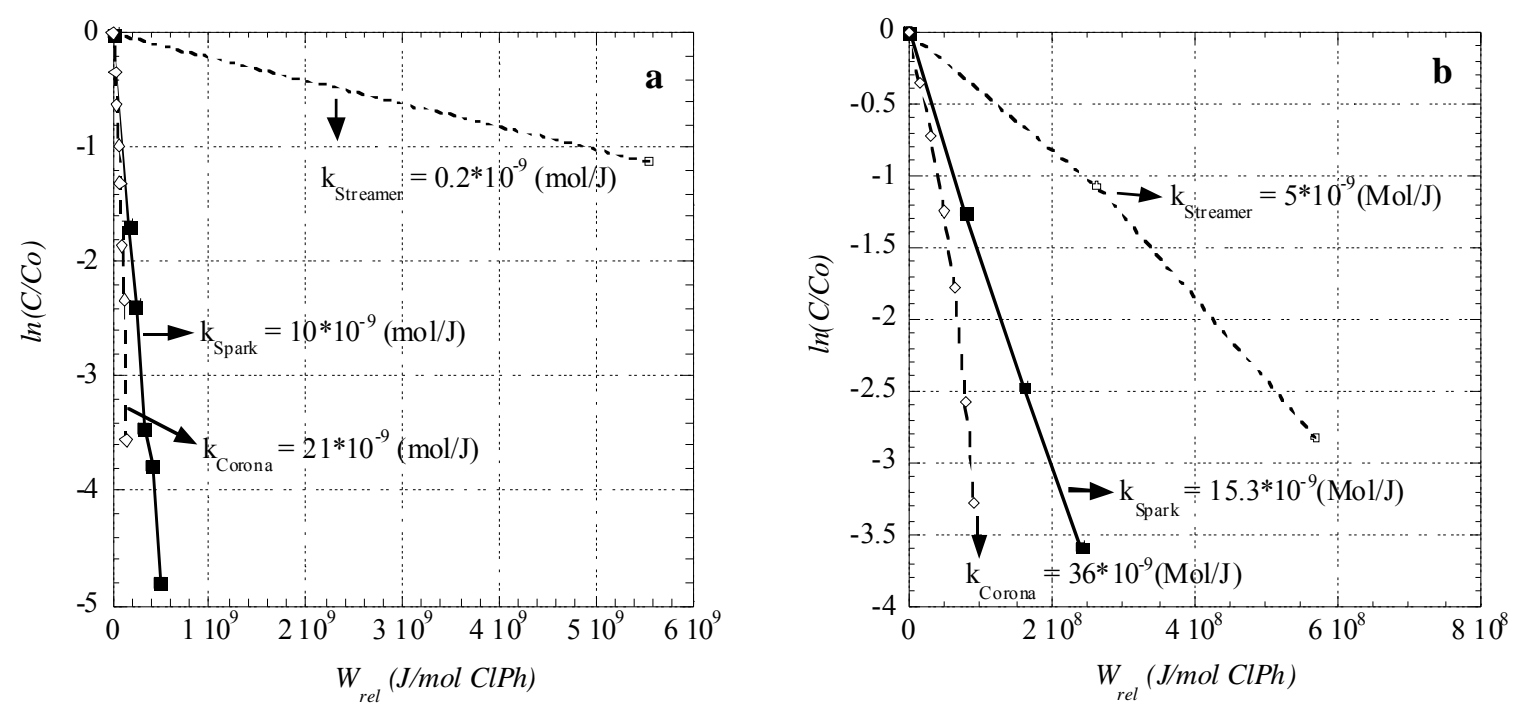

FIGURE 5. 4-chlorophenol removal versus accumulated energy per mole of pollutant $\left(W_{\text {rel }}\right)$ for the 3 pulsed discharge types. (a) without and (b) with $500 \mu \mathrm{M}$ of $\mathrm{FeCl}_{2}$
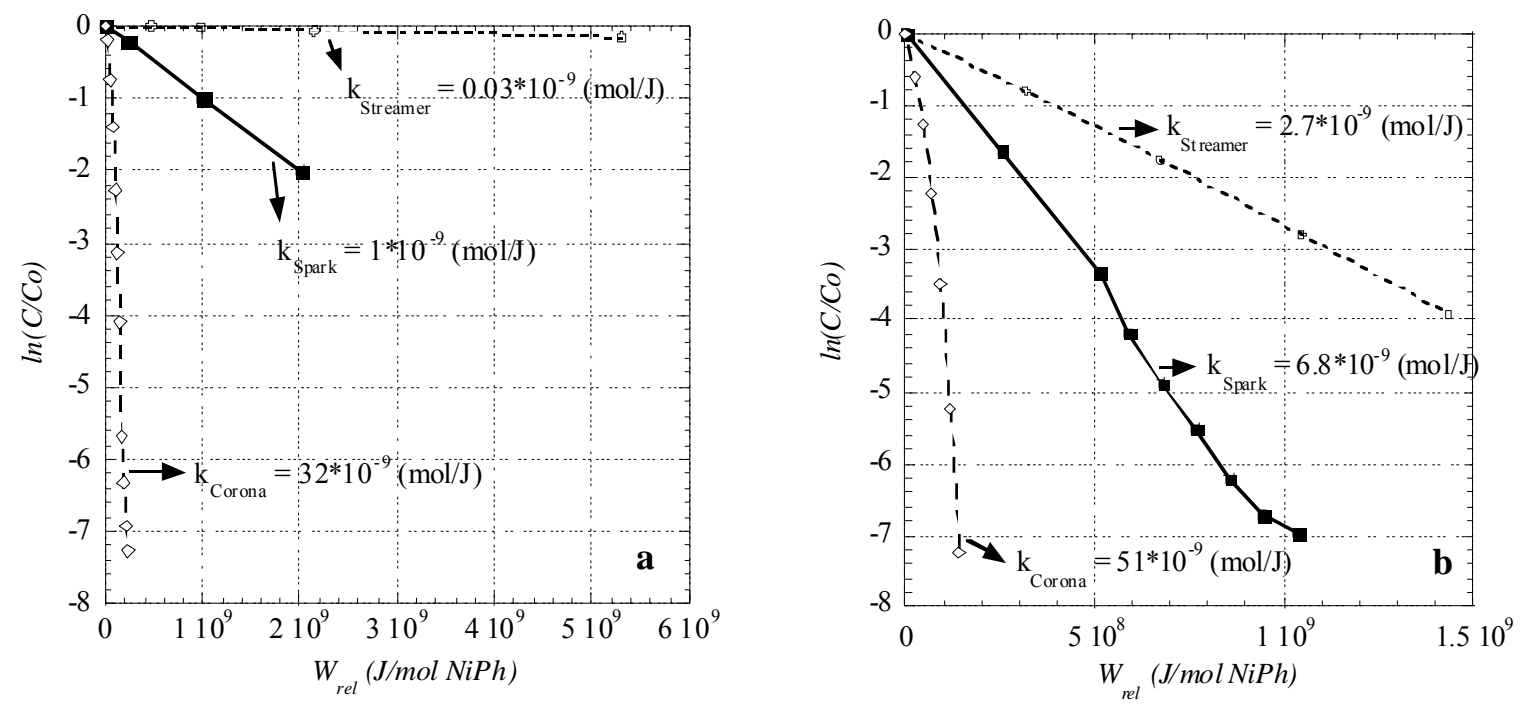

FIGURE 6. 4-nitrophenol removal versus accumulated energy per mole of pollutant $\left(W_{\text {rel }}\right)$ for the 3 pulsed discharge types. (a) without and (b) with $500 \mu \mathrm{M}$ of $\mathrm{FeCl}_{2}$

By adding $500 \mu \mathrm{M}$ of $\mathrm{FeCl}_{2}$, all values of the chemical yield $k$ increase. The largest variations are obtained for the case of streamer discharges in water (x25 for 4-chlorophenol and x90 for 4nitrophenol), and a much lower increase of efficiency is recorded with sparks (resp. x1.5 and x6.8) and corona discharges in air (resp. x1.7 and x1.6). The poor efficiency of streamers in water can probably be explained by a fast recombination of $\mathrm{OH}$ radicals produced by this discharge type. Streamers in water are composed by high pressure gaseous filaments [18], and $\mathrm{OH}$ radicals produced within filaments can quickly recombine to form $\mathrm{H}_{2} \mathrm{O}_{2}$ before diffusing in the surrounding liquid and reacting with pollutants. With $\mathrm{FeCl}_{2}$ added to the solution, the catalytic decomposition of $\mathrm{H}_{2} \mathrm{O}_{2}$ by ferrous ions in acidic solution (Fenton's reaction) yields secondary ${ }^{\circ} \mathrm{OH}$ radicals able to degrade efficiently organic pollutants.

For spark discharges in water and corona in humid air, the influence of ferrous ions is much smaller. In the case of spark discharges, the direct oxidation of pollutant molecules by $\mathrm{OH}$ radicals is much more efficient compared to the streamer, as shown by the much better efficiency obtained without adding $\mathrm{FeCl}_{2}$ to the solution. With sparks, the $\mathrm{H}_{2} \mathrm{O}_{2}$ concentration recorded in pure water is lower than in the case of streamers. This could mean that the process of ${ }^{\circ} \mathrm{OH}$ radical recombination is less 
important. The arc takes place in the expanding gaseous filament previously created by the streamer, and we may suppose that it involves a lower density compared to the streamer, leading to a lower $\mathrm{OH}$ recombination rate. For corona in air, the pollutant degradation is due to ozone and to ${ }^{\circ} \mathrm{OH}$ radicals. The low influence of $\mathrm{FeCl}_{2}$ indicates that ozone is the main active species. The pollutants used here can be degraded by ozone even in acidic solutions [19].

In the case of spark discharges where light emission is important, UV radiation may also contribute to the degradation of 4-chlorophenol (4-nitrophenol is resistant to UV photolysis). This could explain the largest $k$ values obtained for 4-chlorophenol compared to 4-nitrophenol, but no quantitative assessment of this mechanism can be made from the experiments carried out here. A study of the removal of other harmful organic molecules resistant to ozone and UV radiation (for example, succinic acid) could provide answers to this question.

HPLC chromatograms (within the 200-400nm wavelength range) show the removal of both pollutants and intermediate oxidation by-products. As expected, polyhydroxybenzenes (in particular hydroquinone) were observed during the oxidation process. Moreover, the number of oxidation byproducts depends on the pulsed discharge method. The lowest number is observed for streamer discharges in water and the largest for corona discharges in humid air. However, it can be noticed that other by-products such as organic acids are not detected by our HPLC measurements. The full oxidation of pollutants led to mineralization, i.e. production of $\mathrm{CO}_{2}$ and $\mathrm{H}_{2} \mathrm{O}$. Therefore, the measurement of the degree of conversion into $\mathrm{CO}_{2}$ by measuring the total organic content (TOC) would give a more complete evaluation of the true process efficiency. This work is in progress.

In the case of spark discharges in water, the $\mathrm{pH}$ variation seems to indicate an important formation of organic acids, much more difficult to eliminate than the initial pollutant. Measurement of the TOC could thus lead to a different ranking of methods.

\section{CONCLUSION}

The measurement by HPLC of the degradation by electrical discharges of two typical organic pollutants (4-chlorophenol and 4-nitrophenol), correlated to the amount of electrical energy dissipated in discharges has been carried out. These experiments show that the energetic efficiency, expressed in terms of pollutant mole degraded per Joule dissipated, is very different according to the discharge type. Corona discharges in humid air above the water surface show the highest energy efficiency, comparable to direct ozonation processes [6,19]. In addition, on the experimental point of view this process is far more easily carried out, compared to streamer or spark discharges in water: lower voltage and current are required, and the erosion of high voltage electrodes is considerably slower.

Spark discharges are also able to degrade organic compounds by direct oxidation though ${ }^{\circ} \mathrm{OH}$ radicals, but the energy efficiency is lower. The efficiency of streamers in water is even lower, and a significant degradation rate can be attained with streamers only when ferrous ions are added to the solution. Additional investigations such as the measurement of the total organic content, and extension to other pollutants such as organic acids remain necessary in the future to fully assess the actual efficiency of oxidation processes based on electrical discharges.

\section{ACKNOWLEDGEMENTS}

T.H. Dang wishes to thank the French Ministry of Education for providing a grant for this study. Helpful advices from our colleagues of the Laboratory of Water Chemistry and Microbiology, in Poitiers (France) is also greatly acknowledged.

\section{REFERENCES}

[1] J.S. Clements, M. Sato, R.H. Davis, IEEE Trans. Ind. Appl. 23, 224 (1987)

[2] A.A. Joshi, B.R. Locke, P. Arce, W.C. Finney, J. Hazard. Mater. 41, 3 (1995) 
[3] B. Sun, M. Sato, J.S. Clements, J. Electrostatics 39, 189 (1997)

[4] B. Sun, M. Sato, A. Harano, J.S. Clements, J. Electrostatics 43, 115 (1998)

[5] P. Šunka, V. Babický, M. Člupek, P. Lukeš, M. Šimek, J. Schmidt, M. Černák, Plasma Sources Sci. Technol. 8, 258 (1999)

[6] W.F.L.M. Hoeben, E.M. van Veldhuizen, W.R. Rutgers, G.M.W. Kroesen, J. Phys. D: Appl. Phys. 32, L133 (1999).

[7] W.F.L.M. Hoeben, E.M. van Veldhuizen, W.R. Rutgers, C.A.M.G. Cramers and G.M.W. Kroesen, Plasma Sources Sci. Technol. 9, 361 (2000)

[8] D.R. Grymonpré, A.K. Sharma, W.C. Finney, B.R. Locke, Chem. Engineering J. 82, 189 (2001)

[9] M.A. Malik, A. Ghaffar and S.A. Malik, Plasma Sources Sci. Technol. 10, 82 (2001)

[10] M. Sahni, W.C. Finney, B.R. Locke, J. Adv. Oxid. Technol. 8, 105 (2005)

[11] P. Lukes, B.R. Locke, J. Phys. D: Appl. Phys. 38, 4074 (2005)

[12] L. Lei, Y. Zhang, X. Zhang, Y. Shen, J. Electrostatics 66, 16 (2008)

[13] T.H. Dang, A. Denat, O. Lesaint, G. Teissedre, Plasma Sources Sci. Technol. 17, 024013 (2008)

[14] T. Fujii, Y. Aoki, N. Yoshioka, M. Rea, J. Electrostatics 51-52, 8 (2001)

[15] H. Ohneda, A. Harano, M. Sadakata, T. Takarada, J. Electrostatics 55, 321 (2002)

[16] R. Burlica, M.J. Kirkpatrick, B.R. Locke, J. Electrostatics 64, 35 (2006)

[17] R. Peurous, P. Pignolet, B. Held, J. Phys. D: Appl. Phys. 22, 1658 (1989)

[18] W. An, K. Baumung, H. Bluhm, J. Appl. Phys. 101, 053302 (2007)

[19] P.C. Singer, M.D. Gurol, Wat. Res; 17, 1163 (1983) 